\title{
Analyzing preference heterogeneity for soil amenity improvements using discrete choice experiment
}

\author{
Matthew Oliver Ralp Dimal ${ }^{1} \cdot$ Victor Jetten $^{1}$
}

Received: 10 May 2018 / Accepted: 8 September 2018 / Published online: 11 September 2018

(c) The Author(s) 2018

\begin{abstract}
Understanding the soil's economic value is essential in promoting stakeholder participation for its sustainable use and efficient management. However, its less tangible ecological functions have not been measured by conventional market-based valuation approaches. From the decision-making perspective, indirect-use value provides a robust apparatus for examining soil-use alternative and management options. In this study, we analyzed the value of specific soil ecosystem services as indicated by the stakeholders' willingness to pay (WTP) for soil amenity improvements. Using a choice experiment in the Philippine town of Norzagaray, Bulacan, we analyzed the motivations and preferences in soil utility and conservation. Our results showed that in general, the respondents have a positive attitude toward spending for soil improvements. Preference heterogeneity was found to be influenced by spatial determinants and by the socio-demographic characteristics of individual respondents. The results revealed that the respondent's education, income level, and environmental awareness had significant influence on stakeholders' preference and WTP values. Spatial determinants including environmental risks and proximity to amenities were likewise found to explain preference heterogeneity. Despite methodological limitations, this study improves our understanding of soil's explicit value, stakeholder perception, and preference variability, which is useful in designing and implementing more sustainable soil-use management and conservation initiatives.
\end{abstract}

Keywords Soil value $\cdot$ Environmental valuation $\cdot$ Choice experiment $\cdot$ Preference heterogeneity $\cdot$ WTP

\section{Introduction}

The sustainable use and efficient management of soil resources are fundamentally linked with global food security (Pimentel 2006). Similar to other environmental public goods (EPG), soil has often been unappreciated due to its relative abundance, the absence of a pricing mechanism, and the apparent disconnect between perceived and actual economic

Matthew Oliver Ralp Dimal

m.o.r.1.dimal@utwente.nl

1 Faculty of Geo-Information Science and Earth Observation (ITC), University of Twente, 7500 AE Enschede, The Netherlands 
worth (Farnsworth et al. 2015; Schiappacasse et al. 2012). Poor soil management, especially on the uplands, results in the decline of soil amenities which eventually leads to financial burdens. Landcover changes, property rights, farming practices, and land-use policies can have adverse effects on the well-being of the general public. For instance, conversion of forest lands into agricultural fields leads to intensified erosion rates, which results in increased sediment delivery in rivers and reservoirs (Mukundan et al. 2013). Increased sedimentation not only endangers aquatic life forms due to the accompanying nutrients and pollutants but also threatens particular economic activities such as hydroelectric power generation and water supply (Bandara et al. 2001; Bilotta and Brazier 2008). The soil water retention capacity is another vital service which regulates the water needs of flora, fauna, and adjacent communities. Through its water storage capacity, soil plays a crucial role in mitigating flood events during the rainy season by postponing or reducing hydrological peak flows. During the dry periods, this capacity provides a continuous source of water, thus postponing or preventing water deficit. Soil use and vegetation cover significantly impact the interception, infiltration, storage capacity, runoff, and evapotranspiration, which in turn affect the soil's hydrological services (Wünscher et al. 2008). Soil also plays a crucial role in both the emission and absorption of greenhouse gases, reducing carbon emissions and sequestering carbon dioxides into the soil organic matter (Haygarth and Ritz 2009). Carbon sequestration of soil is essential in improving soil quality and in increasing the use efficiency of agronomic inputs (Lal 2008).

Many soil benefits are not well recognized leading to mismanagement and incongruous land-use policies. Private individuals, as well as decision makers and policymakers, demonstrate less willingness to spend on conservation due to imperfect information on the value of soil amenities. In addition to its provisioning features in agricultural production, soil provides a range of fundamental services which includes water flow regulation, carbon sequestration, and erosion control (Bennett et al. 2010; Haygarth and Ritz 2009). But because these soil services are non-consumptive and are collectively enjoyed, traditional pricing mechanisms fail to capture their economic worth. The absence of an economic instrument to assess soil's contributions has resulted in the intensification of resource exhaustion and environmental degradation (Dimal 2015; Jónsson and Davíðsdóttir 2016).

The need to highlight human dependence on well-functioning ecosystems has created the demand for a comprehensive estimation of the environment's economic value (Nestle 2008; Salles 2011). Understanding the aspects of economic value is vital in crafting the short- and long-term soil policies and land-use management (Bennett et al. 2010; Schwilch et al. 2016). The direct-use value, with readily perceivable products and services, can be estimated from a broader array of valuation approaches. In the case of indirect-use value, due to the complex nature of soil amenity functions, a more constrained selection of nonmarket-based techniques is applicative. Environmental economics has developed mechanisms linking the contributions of soil services, both direct and indirect, to human wellness (Costanza et al. 1997; de Groot et al. 2002; Gómez-Baggethun et al. 2010).

The primary goal of this study is to estimate the economic values of specific soil functions by eliciting the stakeholders' stated value for soil conservation. The discrete choice experiment (DCE, explained below) was utilized to evaluate welfare estimates and the marginal utility ${ }^{1}$ values for various soil services from various stakeholders that included both agricultural and non-agricultural households who live within the study area of Norzagaray

\footnotetext{
1 Marginal utility is an essential economic concept that describes the increase in consumer benefit (or utility) with the addition of an extra unit of commodity or service.
} 
Bulacan. Preference heterogeneity would be analyzed by assessing the socio-demographic and spatial determinants influencing stakeholders' preferences. This study aims to contribute to the growing literature on environmental economics and soil science in general, specifically on the under-represented economic valuation of soil conservation. This provides a framework for the use of choice experiment in estimating soil benefits, specifically its various indirect utilities.

\section{Review of literature}

\subsection{Discrete choice experiment}

Discrete choice experiment (DCE) is a survey-based stated preference technique that asks the respondents to choose from different choice sets containing mutually exclusive hypothetical alternatives. It is particularly suited to explore the preference and motivation to invest in soil conservation measures, particularly for public spaces that provide communal public amenities. Considered as being an advanced stated preference approach, a number of studies have utilized DCE for a variety of environmental valuation applications, including in biodiversity enhancement (Bartczak and Meyerhoff 2013; Yao et al. 2014; Zander et al. 2013), ecological restoration (Álvarez-Farizo et al. 2009; Biénabe and Hearne 2006; de Rezende et al. 2015; Lienhoop and Brouwer 2015), health-risk aversion (Veronesi et al. 2014; Vidogbena et al. 2015), and climate change adaptation (Andreopoulos et al. 2015; Nguyen et al. 2013).

The standard DCE technique assumes that the respondents' utility is revealed by a utility function delineated clearly by a defined array of attributes including the price (Colombo et al. 2013). Unlike other non-market valuation approaches such contingent valuation or travel cost method, DCE provides the estimation of value change in some attributes, as well as the compensating surplus measures of multiple changes in attribute levels (Mejía and Brandt 2015). And with the inclusion of cost attribute, the marginal utility can be converted into estimates of the willingness to pay (or accept) attributed to the change in an environmental attribute.

\subsection{Theoretical design}

Two main principles provide the foundations for choice experiments in linking choice behavior being assessed in the survey and the respondents' preferences over a variety of attributes: Lancaster's utility theory (Lancaster 1966) and the random utility theory (McFadden 1974). Lancaster's utility theory states that the value consumers attribute to a particular good is based on the different attributes of products or services from which consumers derive utility, rather than directly from the good. Random utility theory suggests that for a respondent $n$ selecting the option $j$ from a choice set $i=1, \ldots, J$ in a situation $t$, the individual indirect utility $\left(U_{n j t}\right)$ can be decomposed by the utility model:

$$
U_{n j t}=\beta_{n}^{\prime} x_{n j t}+\varepsilon_{n j t},
$$

where $\beta_{n}^{\prime}$ is the coefficient vector and $x_{n j t}$ is the vector of attribute levels of option $j$. The value of the stochastic component $\varepsilon_{n j t}$ reflects the utility function describing the difference between a person's actual utility and the measurable aspect of the utility. This utility 
component is assumed to follow a type 1 extreme-value distribution, so that the probability $P_{n i t}$ for the respondent choosing one option over other alternatives $(j \neq i)$ is

$$
p_{n i t}=\frac{\exp \left(\beta_{n}^{\prime} x_{n i t}\right)}{\sum_{j=1}^{J} \exp \left(\beta_{n}^{\prime} x_{n j t}\right)} .
$$

Some econometric approaches can be used to analyze the probability equation. When the random component $\varepsilon$ is assumed to be independently and identically distributed (IID) with an extreme-value distribution, the choice model can be estimated using the McFadden (1974) conditional logit (CL) model. The CL model assumes the scale parameter to be constant, corresponding to the respondents' having similar choice behavior. The implicit assumption is that the respondents have a homogenous taste for the attributes as presented in the choice experiment.

Another approach that has been used in discrete modeling studies is the random parameter logit (RPL) method (Colombo et al. 2013; Train 1998). Unlike the standard CL models, preference heterogeneity is accounted for in RPL by allowing the parameter vector to vary among individuals with values dependent on the underlying distribution that captures the respondents' taste (Veronesi et al. 2014). It relaxes the independence of irrelevant alternatives (IIA), which can represent any substitution pattern and can explicitly account for unobserved heterogeneity (Gelo and Koch 2012). Both the CL and RPL models produce estimates of the coefficient vector $\beta$ and can be interpreted as the average utility weights of the attributes from the choice tasks (Börger et al. 2014). Although the assumptions for $\beta$ are defined differently, both models produce them using maximum likelihood functions. The marginal WTP for the attribute can then be calculated using the ratio of the coefficients of the attribute and the cost bid attribute:

$$
\mathrm{WTP}_{k}=\frac{\beta_{k}}{-\beta_{\text {cost }}},
$$

where $\beta_{k}$ and $\beta_{\text {cost }}$ are the coefficients of the $k$-attribute and cost, respectively. For the random parameter logit, the $\beta_{k}$ represents the mean of the distribution of the coefficient for each attribute, and the mean marginal WTP value can be calculated by taking the average over the sample distribution of WTP coefficients.

\subsection{Spatial parameters}

Spatial modeling and mapping of economic welfare from ecosystem services for varying policy alternatives have received much attention in environmental research (Termansen et al. 2013). Numerous studies in environmental valuation have exhibited the advantages of incorporating spatial data and physical models into econometric studies (Bohlen and Lewis 2009; Kousky and Walls 2014; Tapsuwan et al. 2015). Spatial variations in environmental functions have a significant influence on the availability and quality of ecosystem services and may have a consequential impact on stakeholder preferences. For instance, proximal and distal effects from anthropogenic improvements and environmental amenities have been shown to influence the formation of stakeholder cognition and preferences (e.g., Borchers and Duke 2012; Bowman et al. 2012; Cai et al. 2011).

In this research, proximity to amenities and hazard susceptibility were utilized to explain stakeholders' choice heterogeneity. Proximity to the river and forests has previously been 
identified as significant determinants influencing economic value (e.g., Pflüger et al. 2010; Snyder et al. 2007; Tapsuwan et al. 2015; White and Leefers 2007). Nearness to waterways and forest areas have been associated with having positive effects on property prices (Nicholls and Crompton 2017; Tapsuwan et al. 2015). Environmental hazards can also affect housing markets and the economic value of environmental goods. The potential loss or disruption of the use of environmental amenities due to hazards can significantly alter value cognition and stakeholder preference. Potential costs associated with natural disasters come in the form of human losses, infrastructure damages, and significant disruptions in economic activities (Shrestha et al. 2016). For instance, high risks of flooding and landslides have been shown to influence the marginal WTP for conservation and mitigation measures (Daniel et al. 2009). Analyzing the complicated relationship of spatial attributes on stakeholder choices and their willingness to pay for soil amenity improvements helps policymakers in evaluating options and costs more efficiently in allocating resources.

\section{Methodology}

\subsection{Study area}

The study area is the agricultural town of Norzagaray $\left(14^{\circ} 55^{\prime} \mathrm{N}, 121^{\circ} 03^{\prime} \mathrm{E}\right)$ from the province of Bulacan, Island of Luzon, the Philippines (as shown in Fig. 1). The municipality is located at the southern tail of the Sierra Madre Mountain Range and is situated about $46 \mathrm{~km}$ north of Metropolitan Manila. Its eastern region consists of steeply sloped mountains covered with primary forests and has been protected by law as a natural reservation. The 62,000-hectare Angat Watershed Forest Reserve has been designated as a protected area to ensure adequate water supply for Metro Manila's needs. During the dry season, it also feeds water for irrigation needs to roughly 84,000 hectares of farmland. The western half of the town constitutes the alienable and disposable land, having a mixed topography of flat and gentle slopes on the extreme west and rolling to hilly terrain along the central and southern parts. Twenty-eight percent of the town's total acreage is used as agricultural, producing mainly rice and other crops such as vegetables, root crops, mango, corn, and banana. Trade and agriculture lead all industries in total employment comprising $28 \%$ and $23 \%$ of the total workforce, while mining and quarrying lead all industries based on tax revenue. Geologically, Norzagaray is abundant with shale and limestone useful in cement manufacturing. There are six main soil types found in the area (Municipal Government of Norzagaray 2010): Buenavista silt loam (0.43\%), Novaliches loam (10.61\%), Novaliches clay loam $(40.45 \%)$, Presna clay loam $(0.90 \%)$, Sibul clay $(6.42 \%)$, and Novaliches soil undifferentiated $(41.19 \%)$. Norzagaray has a tropical monsoon climate with an average rainfall of $2697 \mathrm{~mm}$ and with an average temperature of $26.9{ }^{\circ} \mathrm{C}$ (Municipal Government of Norzagaray 2010).

Previous government assessment reports (Municipal Government of Norzagaray 2010) have shown the locality to be potentially at risk from a variety of natural hazards. Segments of the mountainous areas have a high risk of landslides in the form of differential settlement with lateral downslope movement and minor slump. Deforestation due to illegal logging operations has intensified land stability and has caused massive landslides in the past. Erosion and its associated sediment yield are also a significant concern given its economic impact on power generation and water supply. In the late 1970s to the early 2000 s, the exponential increase in the town's population and the haphazard 


\section{PHILIPPINES}

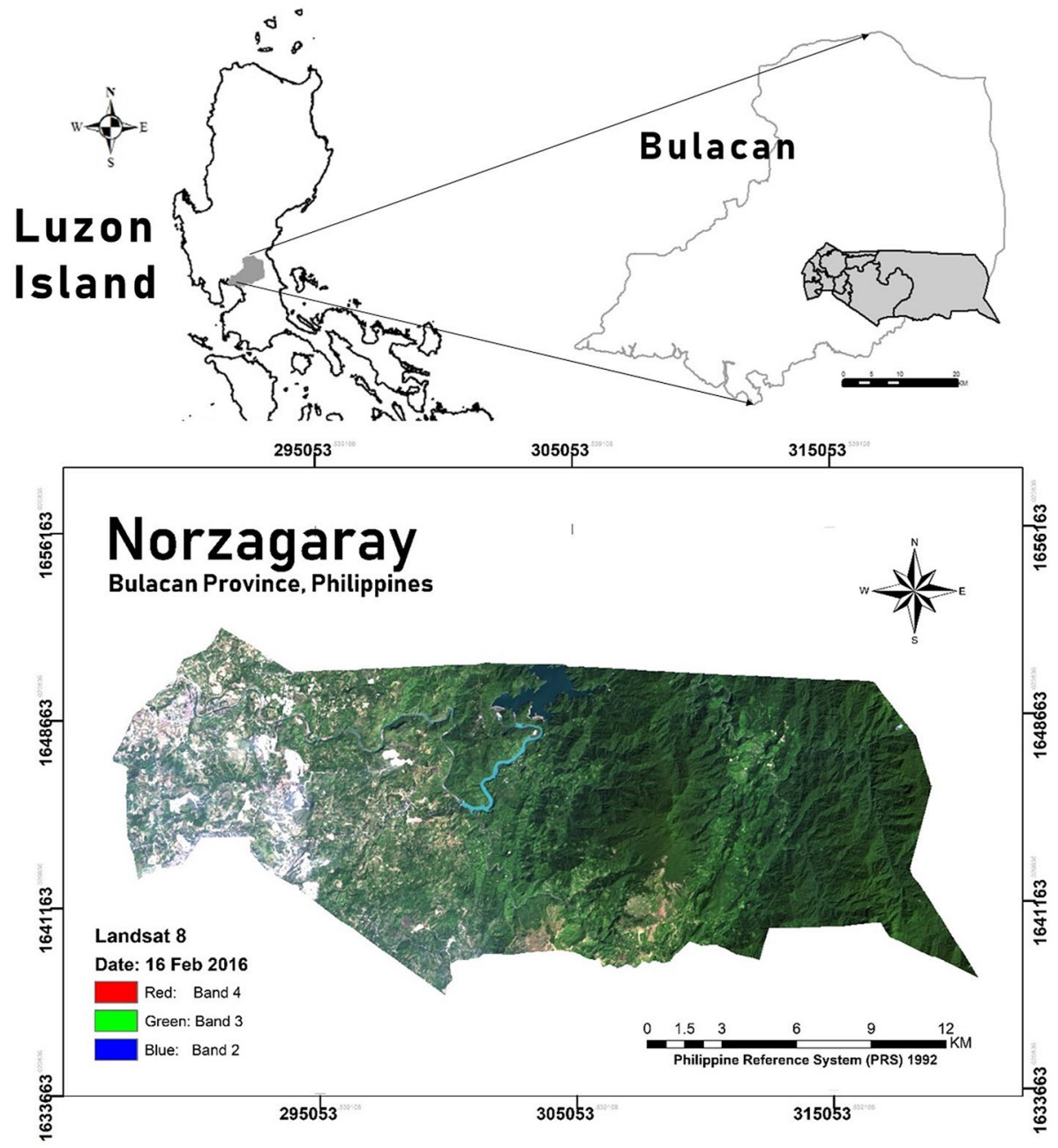

Fig. 1 Map of the study site Norzagaray Bulacan

conversion of forested hills to cultivated lands have been blamed for the increasing intolerable rates of erosion. In response, stricter zoning policies and dedicated reforestation efforts have been implemented to counter soil loss. However, in recent years, the rising farm abandonment has become a significant concern that can conceivably reverse the gains of soil conservation. The expansion of other industries, such as quarrying and mining, coupled with the stagnation in agricultural profit, has led to the dormancy of farmlands, which can lead to higher rates of erosion and increased sediment loading. The sedimentation, especially on the primary reservoir, minimizes the dam's storage capacity which in turn results in a variety of economic and environmental concerns. Aside from generating power and supplying Manila's water needs, the dam serves as 


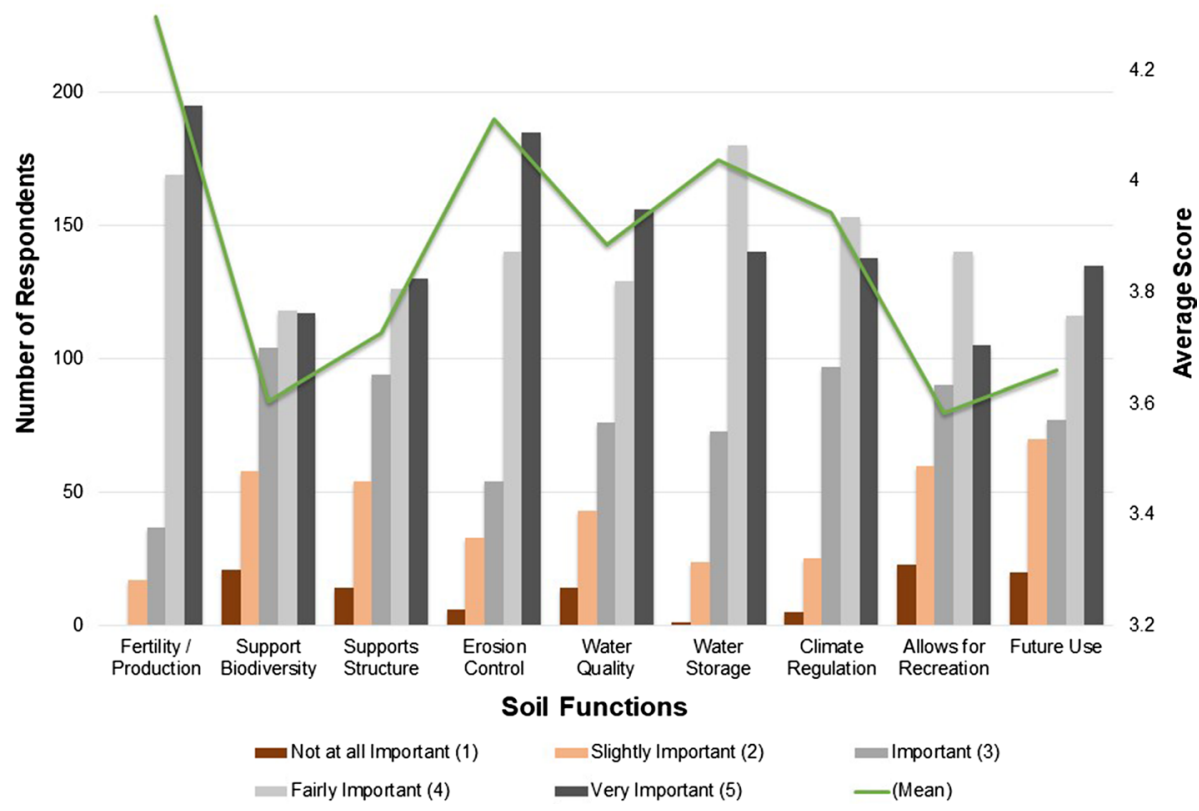

Fig. 2 Chart showing the results of the preliminary survey asking the respondents to gauge the level of importance of the different soil functions

a water control mechanism, regulating water releases to minimize flooding in the lowlands during the rainy season and providing irrigation supply to farmlands during the dry months.

\subsection{Survey design and implementation}

The questionnaire design in this study followed the guidelines specified by Bateman et al. (2002). A preliminary focus group discussion was conducted with seven representatives from the local government, agriculture office, environment office, and farmer leaders in December 2014. Before the conduct of the survey, focus group discussions were organized with the various communities, including the local and provincial government representatives and barangay (community) leaders. The discussions centered around environmental risks, logistical concerns, and the local understanding of soil issues including use, management, and conservation. Quotas for several socio-demographic parameters (e.g., age, income, education) were established to resemble the demographics of the head of the family for the entire population. A draft questionnaire and survey strategy were developed and finalized after a round of pretesting with personnel from the local agriculture's office and barangay officials.

In this particular study, the choice experiment is used to provide a cost estimate for three non-direct-use values: erosion/sediment control, water storage, and carbon sequestration. These soil amenities were chosen based on a preliminary survey conducted a year earlier regarding which soil functions the respondents considered as directly significant to their 


\begin{tabular}{|c|c|c|c|c|}
\hline CASE 1 & & OPTION 1 & OPTION 2 & STATUS QUO \\
\hline $\begin{array}{l}\text { Water Storage Capacity } \\
\text { Increased water infiltration and holding capacity } \\
\text { thereby regulating discharge and mitigates flooding }\end{array}$ & का & $\begin{array}{l}\text { L3: High Improvement } \\
\text { (greaby increases soll's water } \\
\text { holding capacty) }\end{array}$ & $\begin{array}{l}\text { L1: Low Improvement } \\
\text { (Status Quo) }\end{array}$ & $\begin{array}{l}\text { L1: Low Improvement } \\
\text { (Status Quo) }\end{array}$ \\
\hline $\begin{array}{l}\text { Erosion \& Sediment Yield Control } \\
\text { Reduced soil loss and the resulting sediment yield }\end{array}$ & 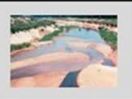 & $\begin{array}{l}\text { L3: High Improvement } \\
\text { (Reduce soil loss by } 20 \% \text { ) }\end{array}$ & $\begin{array}{l}\text { L2: Mod Improvement } \\
\text { (Reduce soll loss by 10\%) }\end{array}$ & $\begin{array}{l}\text { L1: Low Improvement } \\
\text { (Status Quo) }\end{array}$ \\
\hline $\begin{array}{l}\text { Carbon Sequestration Capacity } \\
\text { Increased SOC through reduced C-loss and } \\
\text { increased carbon inputs in soil }\end{array}$ & $=\overline{\bar{T}}=$ & $\begin{array}{l}\text { L1: Low Improvement } \\
\text { (Status Quo) }\end{array}$ & $\begin{array}{l}\text { L2: Mod Improvement } \\
\text { (Moderately reduces } \mathrm{C} \text { loss) }\end{array}$ & $\begin{array}{l}\text { L1: Low Improvement } \\
\text { (Status Quo) }\end{array}$ \\
\hline $\begin{array}{l}\text { Additional Cost } \\
\text { (annual cost for every household) }\end{array}$ & & P 150.00 & P 50.00 & $\begin{array}{c}\text { P0.00 } \\
\text { No Additional Cost }\end{array}$ \\
\hline $\begin{array}{l}\text { Choice for this scenario case: } \\
\text { (please choose your preferred option) }\end{array}$ & & & & $\square$ \\
\hline
\end{tabular}

Fig. 3 Example of the choice set

lives. Through a Likert-scale study, the respondents were asked to rate a list of soil functions from not at all important (1) to very important (5). The results of the preliminary survey are shown in Fig. 2.

A D-efficient partial profile ${ }^{2}$ choice design was implemented, having some guaranteed accuracy in parameter estimation and good prediction capability (Kessels et al. 2011). There were 54 choices generated, partitioned in 18 questionnaires, with each respondent presented with three case sets with varying levels of improvements in soil amenity. Three levels of amenity improvements were used: low (L1), moderate (L2), and high (L3). A fourth attribute was 'cost' which was also given in four levels: P 0, P 50, P 100 , and P150. The payment vehicle (cost) to be used in calculating welfare estimates was in the form of an annual watershed mandatory fee, which has frequently been used in environmental DCE (Morse-Jones et al. 2012). The community fund collected from every household would be used to fund additional conservation strategies aimed at improving soil amenities from the watershed. This was considered as the ideal option with regard to the credibility of the created hypothetical market since the respondents are very familiar with this type of fiscal instrument. Each respondent was asked to answer three randomly generated case sets, with each case set having two randomly generated scenarios and a third option representing the status quo. To minimize ordering effects, the order of the choice sets and the arrangement of soil attributes were altered in each choice set. The status quo alternative became the default third choice option with all Level 1 improvements and no associated financial burden $(\cos t=\mathrm{P} 0.00)$. Figure 3 presents an example of choice sets involving two alternatives and the status quo option.

To help explain stakeholders' heterogeneity of preference, we included socio-demographic characteristics, spatial effects, and environmental consciousness scoring interacted with the attributes of soil ancillary functions. A five-point Likert-scale test was used to

\footnotetext{
2 D-efficient (or d-optimal) design provides straight optimization based on a chosen criterion and the model that will fit it. Instead of using classical designs of fractional factorials, the d-efficient matrices are often non-orthogonal and come with correlated effect estimates.
} 
measure the environmental awareness (EA) score, which centered on the respondents' openness for community initiatives to deal with soil conservation, and perceived awareness regarding soil functions. Supplemental questions were included to mask protest responses. Those who answered 'no' were then excluded from the analysis and deemed as protest responses. Pilot testing was conducted with 18 residents to estimate the time requirements, comprehensibility of questionnaires, and other logistical considerations. This allowed us to approximate the amount of time needed for each interview and to prepare the schedule and other requirements of the survey proper.

\subsection{Survey implementation}

The actual CE survey was conducted from February to April 2015 using face-to-face interviews, with support from the municipal government and Norzagaray's agriculture office. Eleven local folks were trained and employed as support staff for data collection. Each questionnaire took an average of $30 \mathrm{~min}$ to complete, implemented by the lead researcher and at least one support staff. Before the survey proper, a verbal presentation explaining the overview and overall research objectives were provided to the respondents and local leaders (barangay officials and farmer groups).

Stratified random sampling was performed in selecting 450 residents conducted via house visits. To ensure the sample population reflected the agricultural versus non-agricultural demographics of the community, two-thirds of the respondents were targeted to come from agrarian households. Nine of the eleven barangays with substantial agricultural farms were selected as part of this study, with each having 50 households (30 agricultural, 20 non-agricultural) chosen as respondents. Aside from completing the survey questionnaires, we also indicated the geographic coordinates of the respondent. A handheld GPS was used to acquire the spatial coordinates, which was taken on the entrance of the respondent's landholding. As an additional check on the spatial location, a printed remote sensed image of the area was used as a base map to identify the respondent's location.

\section{Results}

Out of the total 450 respondents, 38 responses were eliminated as protest bids which came from respondents who signified their unwillingness to contribute financially to the project. The demographic breakdown of the remaining 412 responses is given in Table 1 . The survey was implemented at an average of $20 \mathrm{~min}$ per respondent. The average age of the respondents was 52, and an average household size was 5.0. For industry type, all non-agricultural employment types were combined into a single class due to limited representation. The other socio-demographic attributes (education, income, age, and household size) were reasonably representative of the Norzagaray population.

The environmental self-assessment survey revealed that majority of the respondents (66\%) had high environmental awareness with an average score of at least 4.0. The majority of the respondents indicated their awareness of the regulating and supporting functions of soil $(91 \%)$ and stated they personally benefitted from soil protection (79\%). Sixty-two percent of those surveyed concurred acceptance for additional remuneration toward watershed preservation. Likewise, the majority of respondents indicated their agreement regarding the protection of watershed as part of their social responsibility (57\%) and that its protection was essential for the sake of the future generation (64\%). 
Table 1 Socioeconomic characteristics of respondents and attributes of their environment

\begin{tabular}{|c|c|c|c|}
\hline Parameter & Description & Mean & $\mathrm{SD}$ \\
\hline Age & Age of respondent in years & 52.35 & 12.32 \\
\hline Household size & Number of family dependents including head & 4.60 & 1.44 \\
\hline Environmentalism score & 1-very low; 2-low; 3-moderate; 4-high; 5-very high & 3.96 & 0.60 \\
\hline Industry type & 1 -agricultural; 2 -non-agricultural & 1.33 & 0.47 \\
\hline Education & $\begin{array}{l}\text { a. Without high school diploma-39.81\% } \\
\text { b. With HS diploma-29.85\% } \\
\text { c. Technical/trade school-20.87\% } \\
\text { d. College degree-25.24\% }\end{array}$ & & \\
\hline Annual income & $\begin{array}{l}\text { a. Less than } \mathrm{P} 40,000-39.56 \% \\
\text { b. } \mathrm{P} 40,000 \text { to } \mathrm{P} 69,999-14.32 \% \\
\text { c. } \mathrm{P} 70,000 \text { to } \mathrm{P} 99,999-20.87 \% \\
\text { d. More than } \mathrm{P} 100,000-25.24 \%\end{array}$ & & \\
\hline Forest zone & $\begin{array}{l}1-w / \text { in } 1.5 \mathrm{~km} \text { from forest reserve; } 2-1.5-3.0 \mathrm{~km} \text { zone; } \\
3-3.0-4.5 \mathrm{~km} \text { zone; } 4-\text { beyond } 4.5 \mathrm{~km} \text { zone }\end{array}$ & 3.28 & 0.02 \\
\hline Water zone & $\begin{array}{l}1 \text {-w/in } 1 \mathrm{~km} \text { zone; } 2-1.0-2.0 \mathrm{~km} \text { zone; } 3 \text {-beyond } 2.0 \mathrm{~km} \\
\text { zone }\end{array}$ & 1.79 & 0.02 \\
\hline Landslide risk & 0 -no risk; 1 -low risk; 2 -moderate risk; 3 -high risk & 0.65 & 0.02 \\
\hline Erosion risk & $\begin{array}{l}0 \text { - negligible to very low risk; } 1 \text {-low risk; } 2 \text {-moderate risk; } \\
\text { 3-high risk; 4-very high risk }\end{array}$ & 1.26 & 0.03 \\
\hline Flood risk & 0 -no risk; 1 -low risk; 2 -medium risk; 3 -high risk & 0.35 & 0.02 \\
\hline
\end{tabular}

Table 2 Summary of estimates for conditional logit (CL) and random parameter logit model (RPL-I)

\begin{tabular}{llll}
\hline Term & CL & \multicolumn{2}{l}{ RPL-I } \\
\cline { 3 - 4 } & Coefficient (error) & Mean coefficient (error) & SD (error) \\
\hline ASC & $-1.4517(0.2412)^{* *}$ & $-1.4561(0.2420)^{* * * *}$ & $0.0188(0.0074)^{* * *}$ \\
Water storage & $0.0338(0.0501)^{* *}$ & $0.0362(0.0502)^{* *}$ & $-0.0558(0.0475)^{* * *}$ \\
Erosion control & $0.3141(0.0502)^{* *}$ & $0.3112(0.0504)^{* *}$ & $-0.0880(0.0530)^{* * *}$ \\
Carbon sequestration & $0.0276(0.0062)^{* *}$ & $0.0287(0.0064)^{* *}$ & $0.0142(0.0541)^{* *}$ \\
Cost & $-0.0053(0.0010)^{* * *}$ & $-0.0053(0.0010)^{* * *}$ & \\
AIC & 2223.640 & 2226.992 & \\
BIC & 2249.189 & 2272.922 & \\
Log likelihood & -1106.796 & -1104.423 & \\
\hline
\end{tabular}

$A S C$ alternative-specific constant, AIC Akaike information criterion, BIC Bayesian information criterion $* * *$ Significant at $1 \%$ level; **Significant at $5 \%$ level; *Significant at $10 \%$ level

\subsection{Utility model estimation}

The parameter estimates from the empirical analyses are given in Table 2. Both models were estimated for comparison, to analyze for the presence of significant random effects. ${ }^{3}$

\footnotetext{
${ }^{3}$ RPL is the more mathematically complex option and relaxes much of the assumptions in CL. If they have very similar results, the presence of random effects does not necessitate further investigation.
} 
Both models generated mean parameter estimates that were statistically significant on at least the $10 \%$ level. The signs of all attribute estimates were consistent on both models. The primary soil attributes showed a priori positive coefficients, while the cost attribute coefficient had a negative sign. These results are in line with basic economic principles indicating behavioral preference for higher-quality goods and lower prices.

For the RPL, various distributions were undertaken and showed minimal effect. Thus, a normal distribution was selected for the survey attributes, except for the cost parameter which was treated as a fixed variable. The number of observations was 1236, given that every respondent answered three choice sets each. The parameter estimates for the RPL models were determined using 2000 random draws. The estimates of the RPL model indicate significant preference heterogeneity, as the standard deviations for the three soil attributes were found to be significant.

A second RPL model (RPL-II) is presented in Table 3, elaborating on the interaction effects of the respondents' socio-demographic attributes. The results suggest that individual preferences may be related to auxiliary factors particularly education, income, and environmental awareness (EA). The EA score was found to have a positive and significant impact on cost and water regulation attribute. Respondents with higher EA scores preferred higher-level improvements in water storage capacity and were willing to spend more for soil improvements. There was significant preference for improving soil's carbon sequestration among highly educated respondents, while higher-income respondents favored improvements in water storage and erosion control. Age was also found to have significant impact on the stakeholders' decision-making process. Older respondents showed significant preference for lower-priced options. As for industry type, there was no substantial evidence indicating statistically significant difference in preference from agricultural and non-agricultural respondents.

To further explain the respondents' choice heterogeneity, spatial effects were integrated into the empirical choice model. Risk/hazard maps in erosion, landslides, and flooding were utilized to determine significant effects in stakeholder preferences. The soil erosion map, as shown in Fig. 4, was generated based on the RUSLE model (see Appendix B for further explanation). The flood hazard (Fig. 5) and landslide vulnerability (Fig. 6) maps were acquired from the provincial government of Bulacan through the Provincial Disaster Risk Reduction and Management Council (PDRRMC). Proximity analyses from major waterways and forest reserves were also executed to show significant effects on preference heterogeneity. The results of the random parameter logit (RPL-3) with spatial covariates are summarized in Table 4. Respondents living near rivers and in flood risk areas were found to significantly favor improvements in water storage capacity. Those living in areas highly vulnerable to erosion were found to prefer improving erosion control.

\subsection{Marginal willingness to pay}

The marginal welfare estimates simulated from the RPL model are reported in Table 5. The soil attributes were treated as ordinal data to calculate the marginal WTP for each improvement level. L1 levels in attribute improvements and $\mathrm{P} 0.00$ in cost were used as baseline values. Welfare estimation revealed that the respondents were willing to pay significantly more for greater levels of improvements in all three soil amenities. The water storage function was shown to elicit the highest marginal WTP, which was followed by erosion control. Superior improvement levels were valued higher for each of 


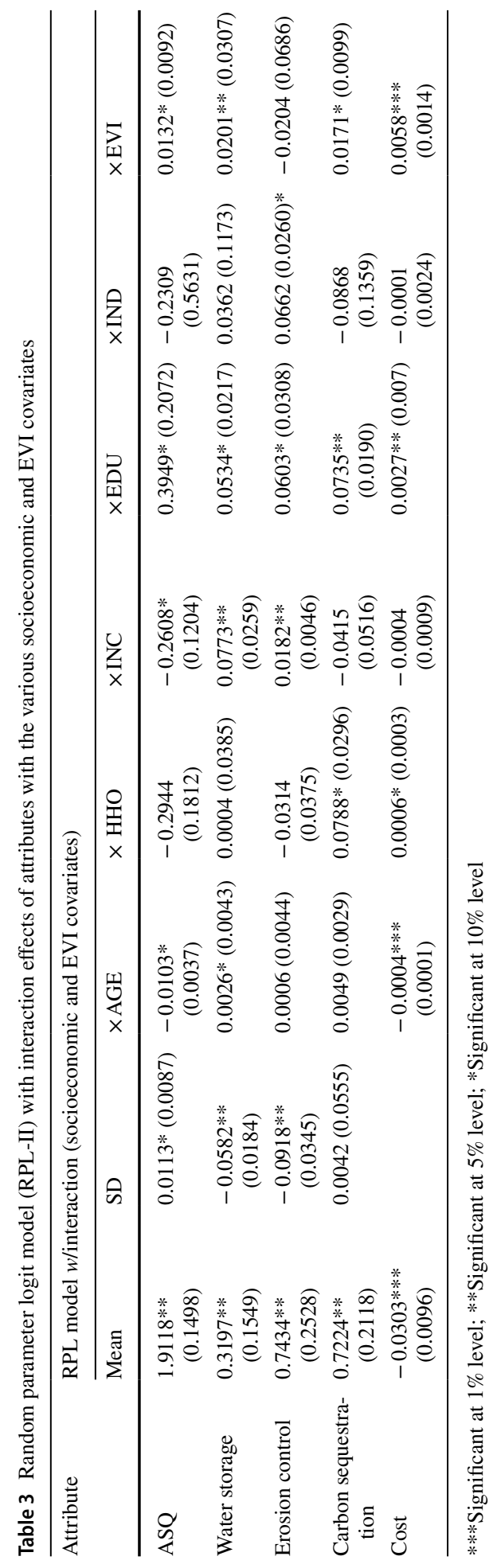




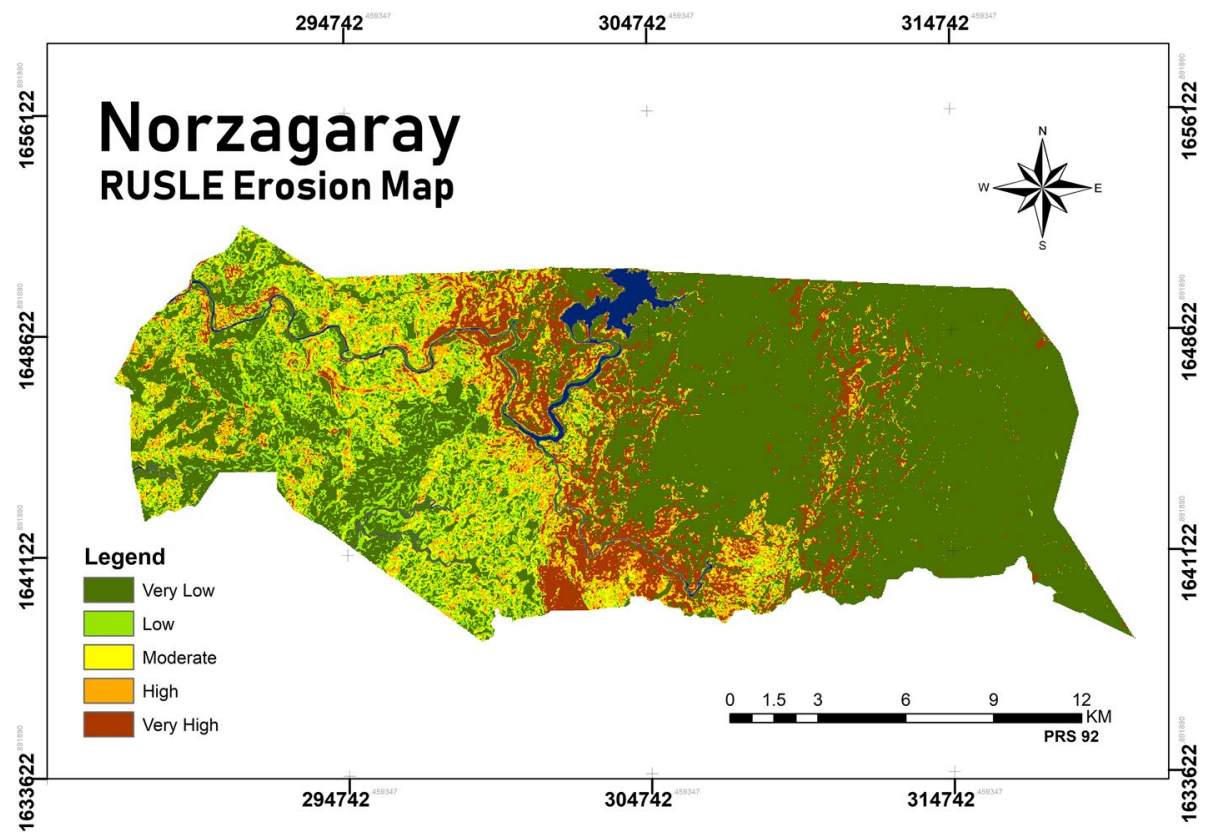

Fig. 4 Generated soil erosion vulnerability map for Norzagaray using RUSLE

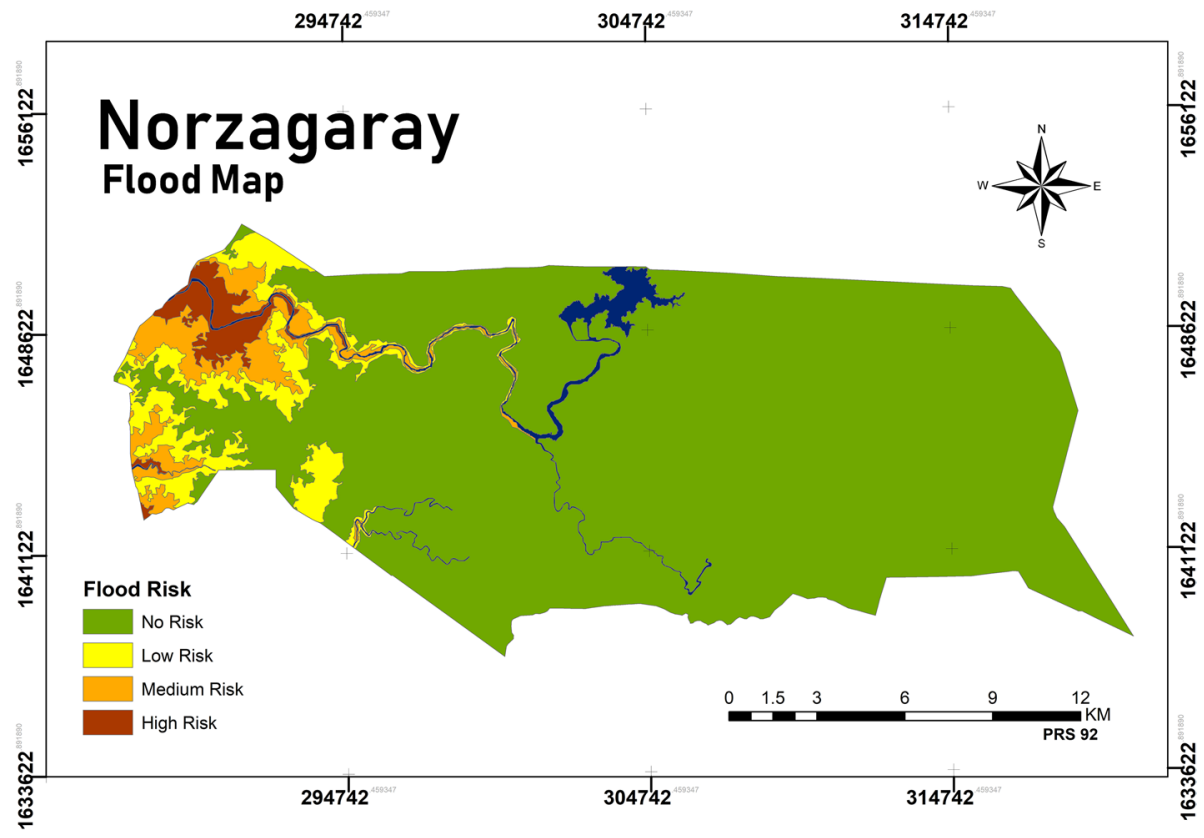

Fig. 5 Flood hazard map for Norzagaray (data provided by Bulacan PDRRMC) 


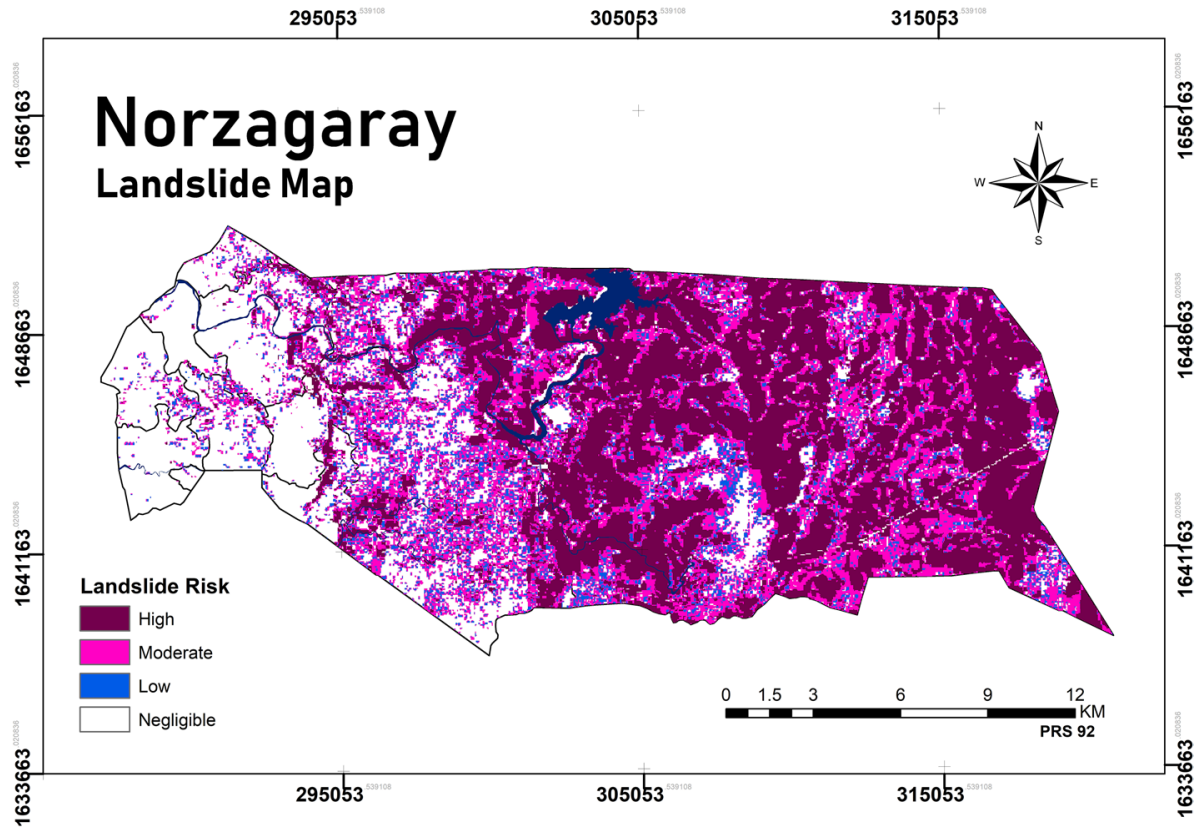

Fig. 6 Landslide risk map for Norzagaray (data provided by Bulacan PDRRMC)

the soil amenities, which would indicate that the respondents were able to discriminate and value all three soil parameters distinctively.

Further analysis was conducted to determine preference variations for soil amenity improvements among the different user groups, specifically between agricultural and non-agricultural households. Table 6 shows the summary of WTP estimates for these stakeholder groups. Both groups were shown to have the highest WTP on water storage capacity, with no significant difference between groups. However, there was significant difference in estimated WTP values for erosion control and carbon sequestration. Agricultural households were estimated to have significantly higher WTP for erosion control, while non-agricultural respondents had higher marginal WTP for carbon sequestration improvements.

\subsection{Spatial effects}

The data points were regrouped into binary clusters to investigate the effects of spatial attributes (see Appendix $\mathrm{C}$ for tables). The presence of environmental risks was found to significantly affect stakeholder preferences. The risk of soil erosion was especially determinative in increasing WTP values. Across all the different soil attributes, respondents in erosion-prone areas were willing to pay more for improvements. There was moderate but significant difference detected for moderate-level improvements in erosion control, with those living in low-incidence areas providing higher WTP values. For the erosion susceptibility parameter, the results showed significant WTP difference 


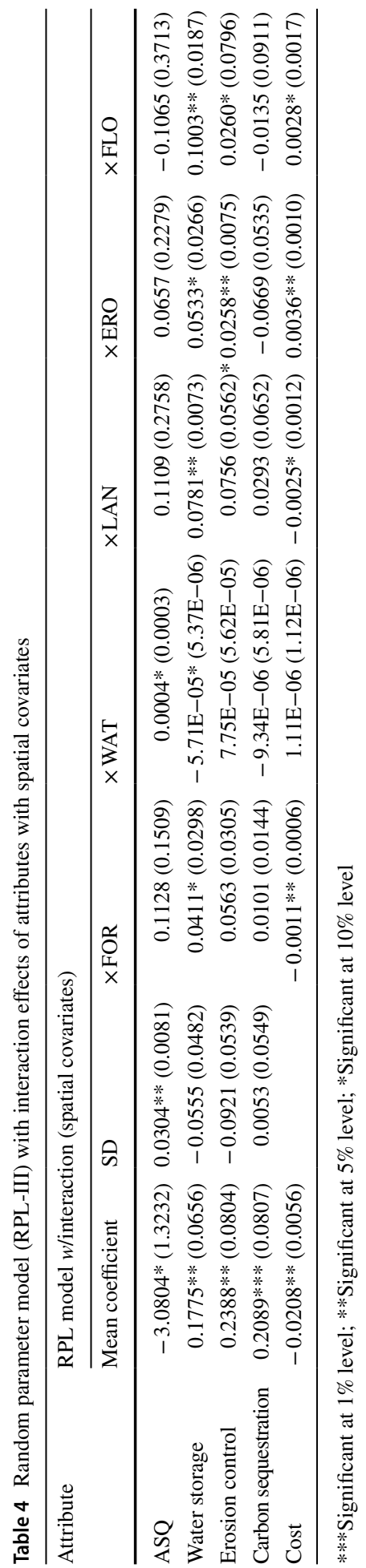


Table 5 Average marginal WTP estimates

\begin{tabular}{lllllll}
\hline Attribute & Level & Improvement & Mean coefficient & MWTP & Lower 95\% & Upper 95\% \\
\hline Water storage & L2 & Moderate & 2.249(0.175) & P64.61 (5.00) & P54.81 & P74.42 \\
& L3 & High & $2.757(0.191)$ & P143.82(6.38) & P131.32 & P156.32 \\
Erosion control & L2 & Moderate & $1.403(0.180)$ & P40.32(4.83) & P30.84 & P49.79 \\
& L3 & High & $1.959(0.157)$ & P96.59(5.44) & P85.93 & P107.25 \\
Carbon sequestration & L2 & Moderate & $1.438(0.140)$ & P41.30(3.83) & P33.80 & P48.81 \\
& L3 & High & $1.029(0.182)$ & P70.87(5.58) & P59.93 & P81.80 \\
\hline
\end{tabular}

All parameter estimates were computed relative to baseline levels (L1)

$\$ 1($ in April 2015) $=\operatorname{PhP} 44.63$

Table 6 Marginal WTP for soil improvements comparing values from agricultural versus non-agricultural respondents

\begin{tabular}{|c|c|c|c|c|c|c|c|}
\hline & \multirow[t]{2}{*}{ Level } & \multicolumn{3}{|l|}{ Farmer } & \multicolumn{3}{|c|}{ Non-farmer } \\
\hline & & $\begin{array}{l}\text { Parameter } \\
\text { coefficient }\end{array}$ & $\begin{array}{l}\text { Change in } \\
\text { WTP }\end{array}$ & SE & $\begin{array}{l}\text { Parameter } \\
\text { coefficient }\end{array}$ & $\begin{array}{l}\text { Change in } \\
\text { WTP }\end{array}$ & SE \\
\hline \multirow[t]{2}{*}{ Water storage } & L2 & 2.472 & 66.55 & 5.92 & 1.898 & 67.23 & 10.28 \\
\hline & L3 & 2.956 & 146.14 & 7.48 & 2.185 & 144.62 & 13.23 \\
\hline \multirow[t]{2}{*}{ Erosion control } & $\mathrm{L} 2$ & 1.737 & 46.77 & 5.66 & 0.776 & 27.48 & 9.58 \\
\hline & L3 & 1.775 & 94.54 & 6.32 & 2.115 & 102.40 & 11.27 \\
\hline \multirow{2}{*}{$\begin{array}{l}\text { Carbon seques- } \\
\text { tration }\end{array}$} & $\mathrm{L} 2$ & 1.430 & 38.50 & 4.37 & 1.400 & 49.60 & 8.17 \\
\hline & L3 & 1.109 & 68.36 & 6.61 & 0.762 & 76.58 & 11.32 \\
\hline
\end{tabular}

in L3 improvements in water storage capacity and erosion control. This suggests that experiencing the impact of soil erosion firsthand can significantly influence the perception regarding the importance of soil services. Landslide risk was also found to influence stakeholder preference. Respondents in high-risk areas indicated significantly higher WTP values for high-level improvements in water storage capacity. Residents living in areas with high risks of landslides were willing to pay significantly higher to improve the soil's water storage capacity and reduce erosion rates. This could be indicative of how the respondents view the relation of the soil's water holding capacity, soil stability, hydrological peak flows, and landslide risks. While landslide remains a highly complex and multifaceted process, the relationship of water retention capacity with landslide risks is more intuitively apparent based on its effect on overland flow and soil stability. This understanding, together with the prevalence of massive landslides in Norzagaray, could have contributed to the significance of landslide risks on influencing preference heterogeneity. For the flood risk parameter, we did not find significant difference in mean WTP estimates in any of the soil parameters. This suggests that the risk of flooding was not a significant determinant for WTP variability. 
For proximity analyses to environmental features, the $1 \mathrm{~km}$ distance from water tributaries and the $1.5 \mathrm{~km}$ distance from forest reserves were used as demarcation to test their spatial effects in WTP variability. In the river proximity analysis, no significant difference in the marginal WTP values was observed among the respondents within and outside the demarcation line. As for the forest proximity analysis, significant differences in marginal WTP were estimated between the clusters, for moderate-level improvements in erosion control and high-level improvements in water storage capacity, erosion control, and carbon sequestration. Residents living nearer to the forest reserves were willing to pay more for improvements in all soil amenity types, which make proximity to forest a prime determinant for WTP. Similar findings from previous studies have found proximity to improvement sites or areas of concern (AOC) as having a significant effect on property prices, economic value, and WTP (e.g., Anthon et al. 2005; Braden et al. 2008; Mueller et al. 2018; Tyrvainen 1997).

\section{Discussion}

Land policies and conservation initiatives often include efficiently managing trade-offs and preserving the long-term economic utility of land (Laurans et al. 2013; Rasul 2009). In many instances, soil management of complex watersheds requires understanding the macro-ecology, balancing the needs of various stakeholders, and understanding the socioeconomic constraints of the proximate communities. From the policy and decision-making perspective, identifying the various ecosystem services and soil amenities contributing directly and indirectly to human wellness is of valuable interest. Together with the direct-use values, the indirect-use values provide crucial metrics required in a more comprehensive examination of management options. In this study, we evaluated several soil functions using choice experiment analysis. The analyses of preference and cost for each soil service allowed further investigation of WTP and preference heterogeneity among the stakeholders.

The results of our RPL models showed the highest marginal WTP was toward improving the soil's water retention capacity. Post-survey discussions with stakeholders revealed that the respondents associated the improvement as a means to avert flooding events and to help replenish the water supply during the dry season. Given Norzagaray's well-pronounced dry and rainy seasons, the town's residents are well familiar with water-related problems such as flooding and water shortage, even on a 'normal' meteorological year. During El Nino and La Nina years, where there is unusual warming or cooling of the waters in the equatorial Pacific, Norzagaray experiences extended very dry and very rainy seasons which are disastrous to the town's agriculture industry. At the time when the survey was being implemented, the town and the rest of the country were making preparations for El Nino projected to occur in the last quarter of 2015. This could have influenced the respondents' preferences given that the last time El Nino occurred in 2010 and Angat Reservoir reached historically low water levels which significantly affected much of the Central Luzon region.

The other soil attributes were also estimated with considerable WTP values. The respondents showed willingness to pay for improvements to minimize soil loss and lessen the sediment discharge into the water systems, even if the national government mainly finances the costs of maintaining the watershed and dredging operations. Post-survey discussions with stakeholders suggest that this could be motivated by a combination of selfinterests and altruistic desires to protect the watershed. Reducing soil erosion rates and 
sedimentation of the reservoir not only extends the economic life of the dam but is viewed by some Norzagaray residents as part of their social responsibility. Carbon sequestration was the least valued among the listed soil amenities, which coincidentally is the least perceivable. Our findings indicate that while the respondents were well versed with climate change issues and showed they were willing to pay for improvements, they viewed carbon sequestration least compared with the other two.

Overall, the respondents showed positive attitude toward spending for soil improvements. The low incidence of status quo responses showed openness to spend more in improving soil amenities. This is despite having a population made up mainly of poor and low-income households, which contradicts the notion that impoverished communities have weak inclination for environmental improvements. Income, education, and environmental consciousness were found to have direct effect on the respondents' preferences. Higherincome and more educated respondents indicated higher WTP values, comparable to the results of similar choice experiments. Higher-income residents are more likely to have available funds for incidental expenditures that can be used for soil management and conservation schemes. The results of our econometric modeling demonstrate that administrators can elicit greater community acceptance for public financed conservation measures if they can demonstrate direct or personal linkages to specific soil amenities. It also shows how spatial and socio-demographic factors could potentially impact stakeholder preferences, which could be later used in strategic planning.

\section{Conclusion}

Using a choice modeling experiment, the stakeholders' willingness to pay for soil conservation was measured and was used as economic metrics for the soil's stated value. A variety of socioeconomic and spatial attributes were found to have significant effect on the explicit valuation of soil in the town of Norzagaray Bulacan, which can be used in crafting suitable land-use policies and conservation plans specific to the area. Understanding the nuances that help formulate people's value perception on ecosystem services help decision makers to consider trade-offs in policy and management approaches. Despite some methodological and data limitations, this study pushes our understanding of how stakeholders perceive and value soil amenities which can then be used for improving soil policies and land-use management. Developing effective policy designs is critical in attaining high participation in soil management, and in reaching conservation goals. This is particularly helpful for rural communities, especially those with limited pecuniary capabilities. Priority preferences diverge among stakeholder groups which can be influenced by socio-demographic and spatial determinants.

In using the discrete choice experiment in estimating soil value, the study was able to estimate the stated value based on how much people would be willing to spend for conservation on specific soil functions. The innovative use of discrete choice experiment in soil valuation allowed the isolation of value for particular amenities, which showed that the respondents attributed economic worth to individual soil functions. The results revealed that for this particular study site, the respondents had preference in improving the soil's water holding capacity, with their preferences affected by various factors including income, education and environmental awareness. The inclusion of environmental risk factors and proximity to environmental amenities also provided additional rationalization to explain preference heterogeneity, which can be further explored in future soil valuation studies. Soil valuation studies, especially those 
that focus on indirect utilities and non-use values, help provide a more inclusive understanding of the underlying nature of soil amenities on human welfare. This is especially critical for soils and other environmental public goods whose economic value has often overlooked.

Open Access This article is distributed under the terms of the Creative Commons Attribution 4.0 International License (http://creativecommons.org/licenses/by/4.0/), which permits unrestricted use, distribution, and reproduction in any medium, provided you give appropriate credit to the original author(s) and the source, provide a link to the Creative Commons license, and indicate if changes were made.

\section{Appendix A: Survey questionnaire}

Self-Evaluation: Please state if you agree or disagree with each of the following statement

1. I am aware of the different indirect functions of soil such as its regulating and supporting functions. $\square$ strongly disagree $\square$ disagree $\square$ neutral $\square$ agree $\square$ strongly agree

2. I personally enjoy the different degradation. $\square$ strongly disagree $\square$ disagree $\square$ neutral $\square$ agree $\square$ strongly agree benefits of protecting the watershed's soil from degradation. $\square$ strongly disagree $\square$ disagree $\square$ neutral $\square$ agree $\square$ strongly agree

3. I consider it a personal obligation to contribute in protecting the watershed from soil conservation measures is acceptable. $\square$ strongly disagree $\square$ disagree $\square$ neutral $\square$ agree $\square$ strongly agree

4. Asking the residents to pay a community-agreed amount for the watershed's future generation. $\square$ strongly disagree $\square$ disagree $\square$ neutral $\square$ agree $\square$ strongly agree

5. Protecting the upper watershed from soil degradation is important for the sake of the conservation.

6. I feel some degree of fulfillment when I do my part in the watershed's soil

$\square$ strongly disagree $\square$ disagree $\square$ neutral $\square$ agree $\square$ strongly agree The Norzagaray part of the Angat Watershed provides a multitude of direct and indirect benefits to our town. In support of the current efforts to preserve and rehabilitate protected areas of the watershed, a plan is proposed to implement an environmental support fund.

1. Would you be willing to contribute to the environmental support fund? $\square$ yes $\square$ no

2. Do you prefer that the fund be: $\square$ voluntary $\square$ mandatory and fixed $\square$ mandatory and progressive

3. If the environmental support fund was to be set-up, and each household would be as asked to pay an annual fee, how much do you think should the amount be set? $\square 0 \square 25 \square 50 \square 75 \quad 100 \square 125 \square 150 \square 175 \square 200$

\section{Appendix B: Developing the erosion vulnerability model}

In implementing the erosion vulnerability model, an updated formulation of the Universal Soil Loss Equation (USLE) was used. The Revised Universal Soil Loss Equation (Renard et al. 1997) was used to estimate potential soil erosion for Norzagaray. The model for erosion vulnerability $(V)$ used in this study is:

$$
V=R K L S C P,
$$

where $V=$ annual soil loss in tons per hectare, $R=$ rainfall erosivity factor, $K=$ soil erodibility factor, $L=$ slope length factor, $S=$ slope steepness factor, $C=$ cover management factor, and $P=$ conservation practice factor. 
In this study, we implemented the RUSLE model using 30-m grid cells. The RUSLE offers a simple and clear methodology to estimate soil erosion potential that does not require the need for complex data (Renschler et al. 1999).

\section{Rainfall erosivity $(R)$}

Rainfall erosivity factor $(R)$ is the parameter approximating the erosive impact of precipitation on soil (i.e., raindrop impact, surface runoff effects). Daily rainfall data of Angat Dam from 1964 to 2014 were used in calculating for $R$ using the equation (Ganasri and Ramesh 2016; Wischmeier and Smith 1978):

$$
R=\sum_{i=1}^{12} 1.735 \times 10^{\left(1.5 \log _{10}\left(\frac{P_{i}^{2}}{\mathrm{P}_{\mathrm{a}}}\right)-0.08188\right)},
$$

where $P_{i}$ is the monthly rainfall $(\mathrm{mm})$ and $P_{\mathrm{a}}$ is the annual rainfall $(\mathrm{mm})$. The rainfall data were obtained from the Watershed Division of the National Power Corporation, which manages the operation of the hydroelectric power plant.

\section{Soil erodibility $(K)$}

Soil erodibility factor $(K)$ gages the susceptibility of soil to erosion as influenced by texture, structure, organic matter content, and soil permeability. The erodibility factor was computed following the equation (Foster et al. 1981):

$$
100 K=\left(2.1 m^{1.14} \times 10^{-4}(12-a)\right)+(3.25(b-2))+(2.5(c-3)),
$$

where $m$ is [silt (\%)+ very fine sand (\%)] [100-clay (\%)]; $a$ is organic matter $(\%) ; b=$ soil structure; and $c=$ soil permeability class. In this study, the geologic/soil map from the Bureau of Soil and Water Management was used, with additional soil data provided by Municipal Agriculture Office.

\section{Combine slope length and steepness (LS)}

The slope length and steepness (LS) factor estimates the effect of topography on the area's vulnerability to soil erosion. Slope length $(L)$ is measured from the origin of the overland flow along its flow path to the location of the concentrated flow or deposition. The slope steepness $(S)$ is the ratio of soil loss from the field gradient with $9 \%$ slope under identical conditions. In this study, four ASTER-GDEM images were processed, georeferenced, and mosaicked in generating the digital elevation model (DEM). The DEM was then used to estimate the combined effect of slope length and steepness with the formula (Moore and Wilson 1992):

$$
\mathrm{LS}=\left(\mathrm{FA} \times \frac{\mathrm{CS}}{22.13}\right)^{0.4} \times\left(\frac{\operatorname{Sin}(S \%)}{0.0896}\right)^{1.3}
$$

where FA is flow accumulation; $\mathrm{CS}=$ size of each raster cell; and $S \%=$ topography's degree of slope. 


\section{Cover management $(C)$}

The cover management $(C)$ factor assesses the impact of varying cropping practices and management on erosion rates. It is commonly used to compare the relative impact of various conservation plans. LandSat8 images captured on February 08, 2014, were used in calculating $C$. Utilizing normalized difference vegetation index (NDVI), $C$ was estimated using the equation (Gutman and Ignatov 1998).

$$
C=1-\frac{\mathrm{NDVI}_{-}-\mathrm{NDVI}_{\min }}{\mathrm{NDVI}_{\max }-\mathrm{NDVI}_{\min }} .
$$

Since the equation only applies to areas with vegetation, other regions were initially masked out in determining the value of $C$ using this equation. The water regions were given the zero values, while the urban areas were given a $c$-value of 1 .

\section{Conservation practice $(P)$}

The conservation practice factor represents the reduction in soil erosion due to conservation measures such as contour farming, strip cropping, and terracing. In this study, no information on the extent of conservation practices was available, and therefore, the value of $(P)$ was pegged to the value 1 .

\section{Implementation of the RUSLE model}

Estimated soil loss in tons/hectare/year was generated in raster mode using ArcGIS10 software. To differentiate soil erosion risk values, the vulnerability results were categorized into five classes: very low ( $<5 \mathrm{t} / \mathrm{ha} / \mathrm{yr})$, low (5-15 t/ha/yr), moderate (15-30 t/ha/yr), high (30-50 t/ha/yr), and very high ( $>50 \mathrm{t} / \mathrm{ha} / \mathrm{yr})$.

\section{Appendix C: Additional tables}

See Tables 7, 8, 9, 10 and 11. 


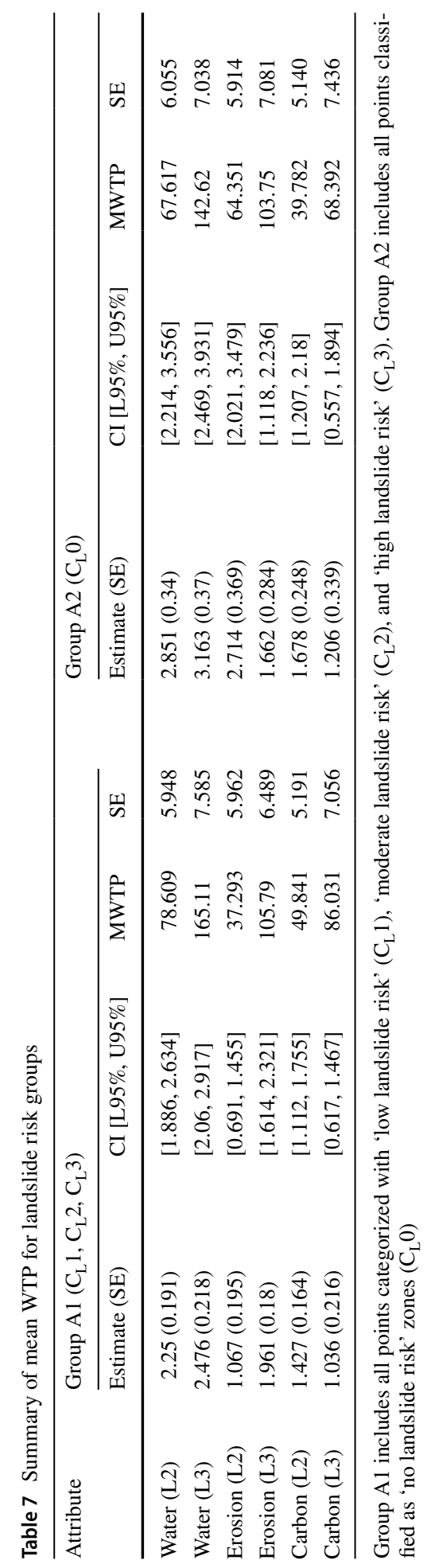




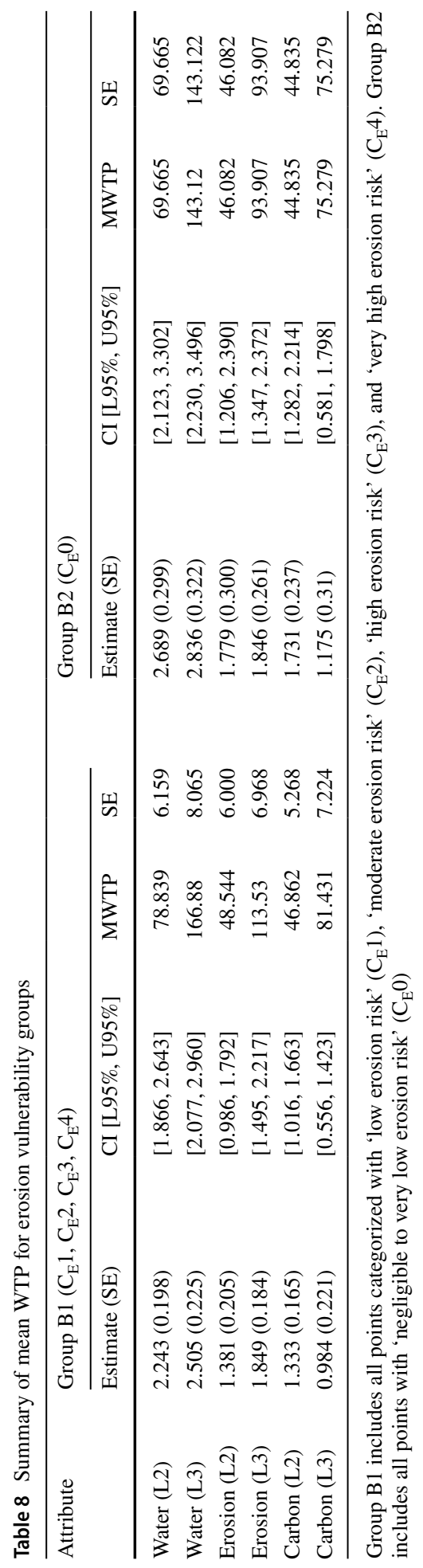




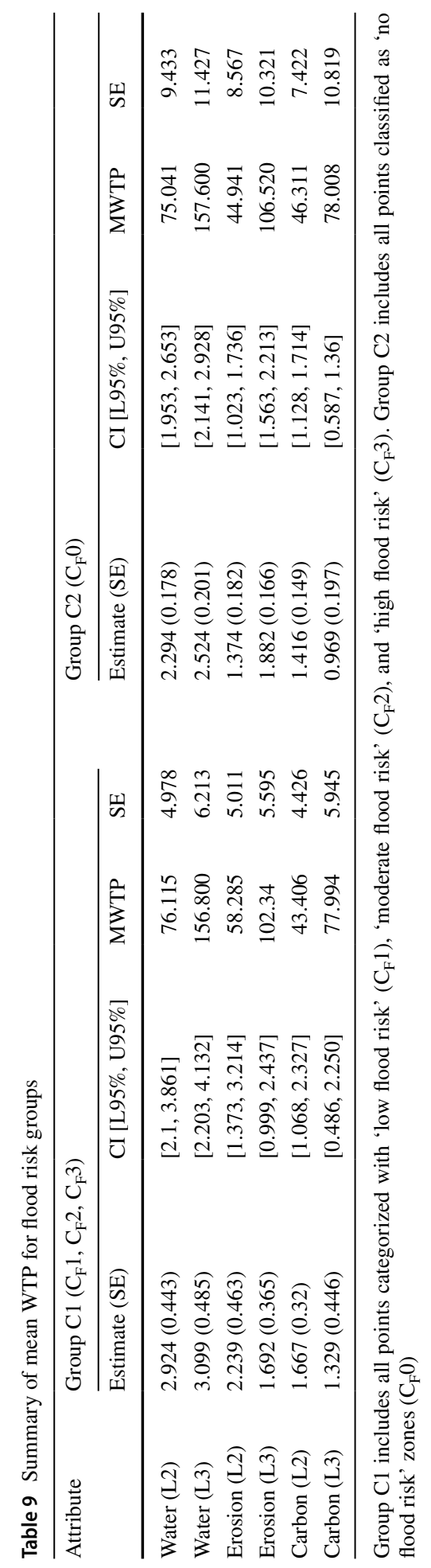




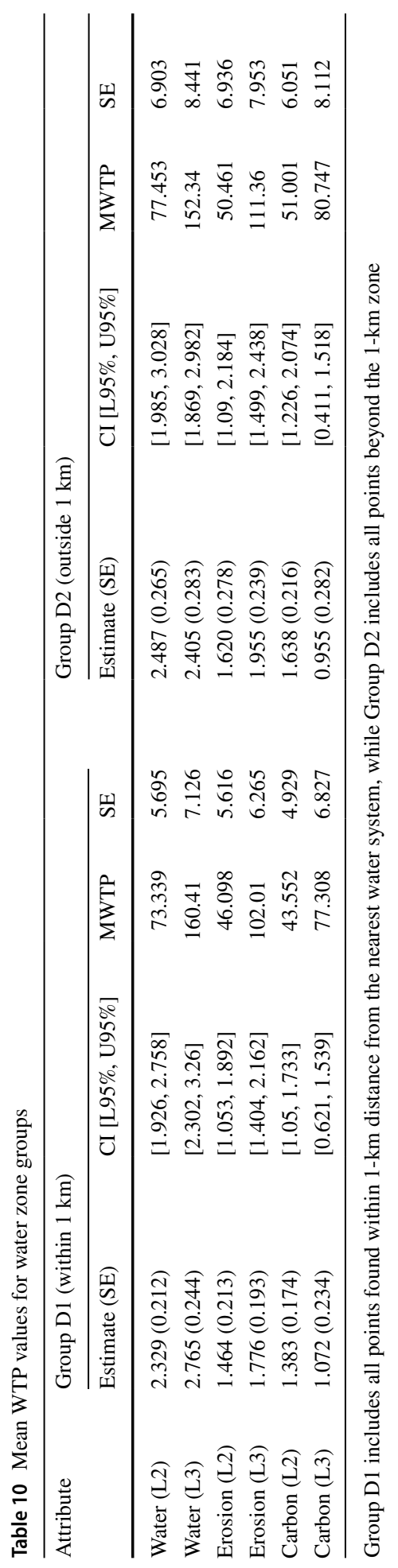




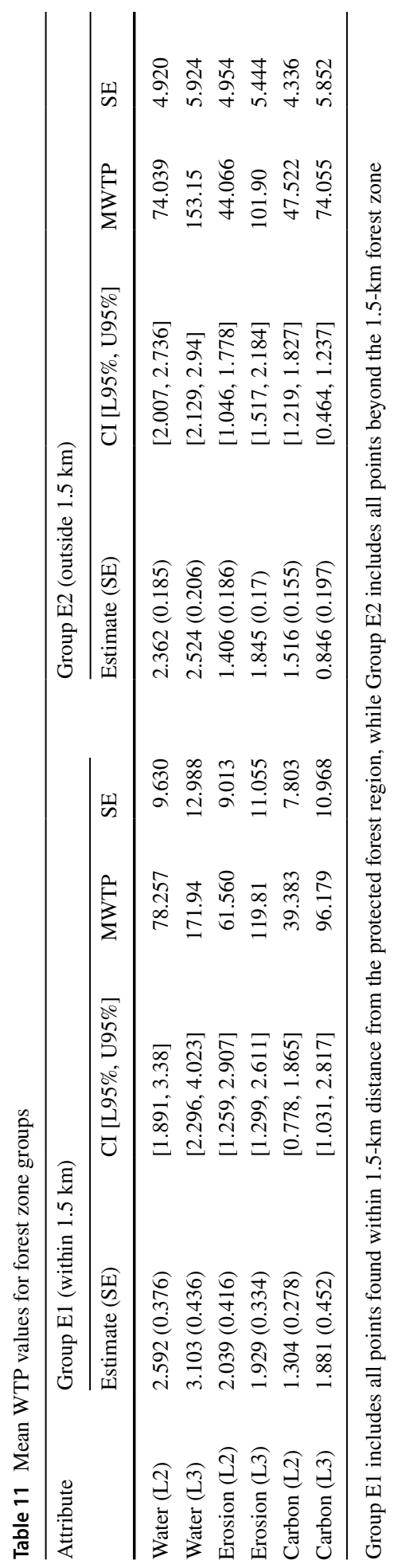




\section{References}

Álvarez-Farizo, B., Gil, J. M., \& Howard, B. J. (2009). Impacts from restoration strategies: Assessment through valuation workshops. Ecological Economics, 68(3), 787-797. https://doi.org/10.1016/j.ecole con.2008.06.012.

Andreopoulos, D., Damigos, D., Comiti, F., \& Fischer, C. (2015). Handling preference heterogeneity for river services' adaptation to climate change. Journal of Environmental Management, 160, 201-211. https://doi.org/10.1016/j.jenvman.2015.06.015.

Anthon, S., Thorsen, B. J., \& Helles, F. (2005). Urban-fringe afforestation projects and taxable hedonic values. Urban Forestry \& Urban Greening, 3(2), 79-91. https://doi.org/10.1016/j.ufug.2004.09.004.

Bandara, J. S., Chisholm, A., Ekanayake, A., \& Jayasuriya, S. (2001). Environmental cost of soil erosion in Sri Lanka: Tax/subsidy policy options. Environmental Modelling and Software, 16(6), 497-508. https ://doi.org/10.1016/s1364-8152(01)00019-6.

Bartczak, A., \& Meyerhoff, J. (2013). Valuing the chances of survival of two distinct Eurasian lynx populations in Poland-Do people want to keep the doors open? Journal of Environmental Management, 129, 73-80. https://doi.org/10.1016/j.jenvman.2013.05.046.

Bateman, I. J., Carson, R. T., Day, B., Hanemann, M., Hanley, N., Hett, T., et al. (2002). Economic valuation with stated preference techniques: A manual. Cheltenham: Edward Elgar Publishing Ltd.

Bennett, L. T., Mele, P. M., Annett, S., \& Kasel, S. (2010). Examining links between soil management, soil health, and public benefits in agricultural landscapes: An Australian perspective. Agriculture, Ecosystems \& Environment, 139(1-2), 1-12. https://doi.org/10.1016/j.agee.2010.06.017.

Biénabe, E., \& Hearne, R. R. (2006). Public preferences for biodiversity conservation and scenic beauty within a framework of environmental services payments. Forest Policy and Economics, 9(4), 335-348. https://doi.org/10.1016/j.forpol.2005.10.002.

Bilotta, G. S., \& Brazier, R. E. (2008). Understanding the influence of suspended solids on water quality and aquatic biota. Water Research, 42(12), 2849-2861. https://doi.org/10.1016/j.watres.2008.03.018.

Bohlen, C., \& Lewis, L. Y. (2009). Examining the economic impacts of hydropower dams on property values using GIS. Journal of Environmental Management, 90(Suppl 3), S258-S269. https://doi. org/10.1016/j.jenvman.2008.07.026.

Borchers, A. M., \& Duke, J. M. (2012). Capitalization and proximity to agricultural and natural lands: Evidence from Delaware. Journal of Environmental Management, 99, 110-117. https://doi.org/10.1016/j. jenvman.2012.01.011.

Börger, T., Hattam, C., Burdon, D., Atkins, J. P., \& Austen, M. C. (2014). Valuing conservation benefits of an offshore marine protected area. Ecological Economics, 108, 229-241. https://doi.org/10.1016/j. ecolecon.2014.10.006.

Bowman, T., Tyndall, J. C., Thompson, J., Kliebenstein, J., \& Colletti, J. P. (2012). Multiple approaches to valuation of conservation design and low-impact development features in residential subdivisions. Journal of Environmental Management, 104, 101-113. https://doi.org/10.1016/j.jenvman.2012.02.006.

Braden, J. B., Taylor, L. O., Won, D., Mays, N., Cangelosi, A., \& Patunru, A. A. (2008). Economic benefits of remediating the Buffalo River, New York area of concern. Journal of Great Lakes Research, 34(4), 631-648. https://doi.org/10.3394/0380-1330-34.4.631.

Cai, B., Cameron, T. A., \& Gerdes, G. R. (2011). Distal order effects in stated preference surveys. Ecological Economics, 70(6), 1101-1108. https://doi.org/10.1016/j.ecolecon.2010.12.018.

Colombo, S., Christie, M., \& Hanley, N. (2013). What are the consequences of ignoring attributes in choice experiments? Implications for ecosystem service valuation. Ecological Economics, 96, 25-35. https:// doi.org/10.1016/j.ecolecon.2013.08.016.

Costanza, R., d'Arge, R., de Groot, R., Farber, S., Grasso, M., Hannon, B., et al. (1997). The value of the world's ecosystem services and natural capital. Nature, 387(6630), 253-260. https://doi. org/10.1038/387253a0.

Daniel, V. E., Florax, Raymond J. G. M., \& Rietveld, P. (2009). Flooding risk and housing values: An economic assessment of environmental hazard. Ecological Economics, 69(2), 355-365. https://doi. org/10.1016/j.ecolecon.2009.08.018.

de Groot, R. S., Wilson, M. A., \& Boumans, Roelof M. J. (2002). A typology for the classification, description and valuation of ecosystem functions, goods and services. Ecological Economics, 41(3), 393-408. https://doi.org/10.1016/s0921-8009(02)00089-7.

de Rezende, C., Eduardo, J. R., Kahn, L. P., \& Vásquez, W. F. (2015). An economic valuation of mangrove restoration in Brazil. Ecological Economics, 120, 296-302. https://doi.org/10.1016/j.ecole con.2015.10.019.

Dimal, M. O. L. (2015). Integrating participation in estimating soil's economic value. International Journal of Engineering Science (1), 1-9. http://www.ijmse.org/Volume6/Issue1/paper1.pdf. Accessed 28 Mar 2018. 
Farnsworth, K. D., Adenuga, A. H., \& de Groot, R. S. (2015). The complexity of biodiversity: A biological perspective on economic valuation. Ecological Economics, 120, 350-354. https://doi.org/10.1016/j. ecolecon.2015.10.003.

Foster, G. R., McCool, D. K., Renard, K. G., \& Moldenhauer, W. C. (1981). Conversion of the universal soil loss equation to SI metric units. Journal of Soil and Water Conservation, 36(6), 355-359.

Ganasri, B. P., \& Ramesh, H. (2016). Assessment of soil erosion by RUSLE model using remote sensing and GIS-A case study of Nethravathi Basin. Geoscience Frontiers, 7(6), 953-961. https://doi. org/10.1016/j.gsf.2015.10.007.

Gelo, D., \& Koch, S. F. (2012). Does one size fit all? Heterogeneity in the valuation of community forestry programs. Ecological Economics, 74, 85-94. https://doi.org/10.1016/j.ecolecon.2011.11.010.

Gómez-Baggethun, E., de Groot, R., Lomas, P. L., \& Montes, C. (2010). The history of ecosystem services in economic theory and practice: From early notions to markets and payment schemes. Ecological Economics, 69(6), 1209-1218. https://doi.org/10.1016/j.ecolecon.2009.11.007.

Gutman, G., \& Ignatov, A. (1998). The derivation of the green vegetation fraction from NOAA/AVHRR data for use in numerical weather prediction models. International Journal of Remote Sensing, 19(8), 1533-1543. https://doi.org/10.1080/014311698215333.

Haygarth, P. M., \& Ritz, K. (2009). The future of soils and land use in the UK: Soil systems for the provision of land-based ecosystem services. Land Use Policy, 26, S187-S197. https://doi.org/10.1016/j. landusepol.2009.09.016.

Jónsson, J. Ö. G., \& Davíðsdóttir, B. (2016). Classification and valuation of soil ecosystem services. Agricultural Systems, 145, 24-38. https://doi.org/10.1016/j.agsy.2016.02.010.

Kessels, R., Jones, B., \& Goos, P. (2011). Bayesian optimal designs for discrete choice experiments with partial profiles. Journal of Choice Modelling, 4(3), 52-74. https://doi.org/10.1016/s1755-5345(13)70042-3.

Kousky, C., \& Walls, M. (2014). Floodplain conservation as a flood mitigation strategy: Examining costs and benefits. Ecological Economics, 104, 119-128. https://doi.org/10.1016/j.ecolecon.2014.05.001.

Lal, R. (2008). Sequestration of atmospheric $\mathrm{CO}_{2}$ in global carbon pools. Energy \& Environmental Science, 1(1), 86-100. https://doi.org/10.1039/b809492f.

Lancaster, K. J. (1966). A new approach to consumer theory. Journal of Political Economy, 2, 132-157.

Laurans, Y., Rankovic, A., Bille, R., Pirard, R., \& Mermet, L. (2013). Use of ecosystem services economic valuation for decision making: Questioning a literature blindspot. Journal of Environmental Management, 119, 208-219. https://doi.org/10.1016/j.jenvman.2013.01.008.

Lienhoop, N., \& Brouwer, R. (2015). Agri-environmental policy valuation: Farmers' contract design preferences for afforestation schemes. Land Use Policy, 42, 568-577. https://doi.org/10.1016/j.landusepol .2014.09.017.

McFadden, D. (1974). Conditional logit analysis of qualitative choice behavior. Frontiers in Econometrics $105-142$.

Mejía, C. V., \& Brandt, S. (2015). Managing tourism in the Galapagos Islands through price incentives: A choice experiment approach. Ecological Economics, 117, 1-11. https://doi.org/10.1016/j.ecole con.2015.05.014.

Moore, I. D., \& Wilson, J. P. (1992). Length-slope factors for the revised universal soil loss equation: Simplified method of estimation. Journal of Soil and Water Conservation, 47(5), 423-428.

Morse-Jones, S., Bateman, I. J., Kontoleon, A., Ferrini, S., Burgess, N. D., \& Kerry Turner, R. (2012). Stated preferences for tropical wildlife conservation amongst distant beneficiaries: Charisma, endemism, scope and substitution effects. Ecological Economics, 78, 9-18. https://doi.org/10.1016/j.ecole con.2011.11.002.

Mueller, J. M., Springer, A. E., \& Lima, R. E. (2018). Willingness to pay for forest restoration as a function of proximity and viewshed. Landscape and Urban Planning, 175, 23-33. https://doi.org/10.1016/j. landurbplan.2018.03.006.

Mukundan, R., Pradhanang, S. M., Schneiderman, E. M., Pierson, D. C., Anandhi, A., Zion, M. S., et al. (2013). Suspended sediment source areas and future climate impact on soil erosion and sediment yield in a New York City water supply watershed, USA. Geomorphology, 183, 110-119. https://doi. org/10.1016/j.geomorph.2012.06.021.

Municipal Government of Norzagaray. (2010). Comprehensive land use plan (2011-2020). In CLUP (pp. 5-65). Norzagaray, Bulacan: Municipal Government of Norzagaray.

Nestle, I. (2008). Evaluation of risk in cost-benefit analysis of climate change. In B. Hansjürgens \& R. Antes (Eds.), Economics and management of climate change (pp. 23-35). New York: Springer.

Nguyen, T. C., Robinson, J., Kaneko, S., \& Komatsu, S. (2013). Estimating the value of economic benefits associated with adaptation to climate change in a developing country: A case study of improvements in tropical cyclone warning services. Ecological Economics, 86, 117-128. https://doi.org/10.1016/j.ecole con.2012.11.009. 
Nicholls, S., \& Crompton, J. L. (2017). The effect of rivers, streams, and canals on property values. River Research and Applications, 33(9), 1377-1386. https://doi.org/10.1002/rra.3197.

Pflüger, Y., Rackham, A., \& Larned, S. (2010). The aesthetic value of river flows: An assessment of flow preferences for large and small rivers. Landscape and Urban Planning, 95(1-2), 68-78. https://doi. org/10.1016/j.landurbplan.2009.12.004.

Pimentel, D. (2006). Soil erosion: A food and environmental threat. Environment, Development and Sustainability, 8(1), 119-137. https://doi.org/10.1007/s10668-005-1262-8.

Rasul, G. (2009). Ecosystem services and agricultural land-use practices: A case study of the Chittagong Hill tracts of Bangladesh. Sustainability: Science, Practice, and Policy, 5(2), 15-27.

Renard, K. G., Foster, G. R., Weesies, G. A., McCool, D. K., \& Yoder, D. C. (1997). Predicting soil erosion by water: A guide to conservation planning with the revised universal soil loss equation (RUSLE). In USDA.

Renschler, C. S., Mannaerts, C., \& Diekkruger, B. (1999). Evaluating spatial and temporal variability in soil erosion risk-Rainfall erosivity and soil loss ratios in Andalusia, Spain. Catena, 34(3-4), 209-225. https://doi.org/10.1016/S0341-8162(98)00117-9.

Salles, J.-M. (2011). Valuing biodiversity and ecosystem services: Why put economic values on Nature? Comptes Rendus Biologies, 334(5-6), 469-482. https://doi.org/10.1016/j.crvi.2011.03.008.

Schiappacasse, I., Nahuelhual, L., Vasquez, F., \& Echeverria, C. (2012). Assessing the benefits and costs of dryland forest restoration in central Chile. Journal of Environmental Management, 97, 38-45. https:// doi.org/10.1016/j.jenvman.2011.11.007.

Schwilch, G., Bernet, L., Fleskens, L., Giannakis, E., Leventon, J., Marañón, T., et al. (2016). Operationalizing ecosystem services for the mitigation of soil threats: A proposed framework. Ecological Indicators, 67, 586-597. https://doi.org/10.1016/j.ecolind.2016.03.016.

Shrestha, B. B., Okazumi, T., Miyamoto, M., \& Sawano, H. (2016). Flood damage assessment in the Pampanga river basin of the Philippines. Journal of Flood Risk Management, 9(4), 355-369. https://doi. org/10.1111/jfr3.12174.

Snyder, S. A., Kilgore, M. A., Hudson, R., \& Donnay, J. (2007). Determinants of forest land prices in northern Minnesota: A hedonic pricing approach. Forest Science, 53(1), 25-36.

Tapsuwan, S., Polyakov, M., Bark, R., \& Nolan, M. (2015). Valuing the Barmah-Millewa forest and in stream river flows: A spatial heteroskedasticity and autocorrelation consistent (SHAC) approach. Ecological Economics, 110, 98-105. https://doi.org/10.1016/j.ecolecon.2014.12.008.

Termansen, M., McClean, C. J., \& Jensen, F. S. (2013). Modelling and mapping spatial heterogeneity in forest recreation services. Ecological Economics, 92, 48-57. https://doi.org/10.1016/j.ecole con.2013.05.001.

Train, K. E. (1998). Recreation demand models with taste differences over people. Land Economics, 74(2), 230-239.

Tyrvainen, L. (1997). The amenity value of the urban forest: An application of the hedonic pricing method. Landscape and Urban Planning, 37(3-4), 211-222. https://doi.org/10.1016/S0169-2046(97)80005-9.

Veronesi, M., Chawla, F., Maurer, M., \& Lienert, J. (2014). Climate change and the willingness to pay to reduce ecological and health risks from wastewater flooding in urban centers and the environment. Ecological Economics. https://doi.org/10.1016/j.ecolecon2013.12.005.

Vidogbena, F., Adegbidi, A., Tossou, R., Assogba-Komlan, F., Ngouajio, M., Martin, T., et al. (2015). Control of vegetable pests in Benin-Farmers' preferences for eco-friendly nets as an alternative to insecticides. Journal of Environmental Management, 147, 95-107. https://doi.org/10.1016/j.jenvman.2014.09.010.

White, E. M., \& Leefers, L. A. (2007). Influence of natural amenities on residential property values in a rural setting. Society \& Natural Resources, 20(7), 659-667. https://doi.org/10.1080/08941920601171998.

Wischmeier, W. H., \& Smith, D. D. (1978). Predicting rainfall erosion losses: A guide to conservation planning. In USDA. Washing D.C.: Government Printing Office.

Wünscher, T., Engel, S., \& Wunder, S. (2008). Spatial targeting of payments for environmental services: A tool for boosting conservation benefits. Ecological Economics, 65(4), 822-833. https://doi. org/10.1016/j.ecolecon.2007.11.014.

Yao, R. T., Scarpa, R., Turner, J. A., Barnard, T. D., Rose, J. M., Palma, João H. N., et al. (2014). Valuing biodiversity enhancement in New Zealand's planted forests: Socioeconomic and spatial determinants of willingness-to-pay. Ecological Economics, 98, 90-101. https://doi.org/10.1016/j.ecole con.2013.12.009.

Zander, K. K., Signorello, G., De Salvo, M., Gandini, G., \& Drucker, A. G. (2013). Assessing the total economic value of threatened livestock breeds in Italy: Implications for conservation policy. Ecological Economics, 93, 219-229. https://doi.org/10.1016/j.ecolecon.2013.06.002. 